Ks. Stanislow Mędala CM

\title{
FORMY INTERPRETACJI BIBLII WI JUDAIZMIE OKRESU MIĘDZYTESTAMENTALNEGO
}

Zjawisko interpretacji Biblii $\mathrm{w}$ judaizmie starożytnym od dawna przykuwa uwagę biblistów, gdyż służy do zrozumienia podłoża Nowego Testamentu ${ }^{1}$. Do zbadania różnych aspektów tego zjawiska przyczyniły się niewątpliwie odkrycia pism kumrańskich i targumu palestyńskiego do Pięcioksięgu w Bibliotece Watykańskej w kodeksie Neofiti 1, a także rozwój hermeneutyki biblijnej. Niemniej wiele zagadnień pozostaje nadal niewyświetlonych. Interpretacja Starego Testamentu $\mathrm{w}$ strożytnym judaizmie łączy się bowiem $\mathrm{z}$ takimi zagadnieniami, jak historyczno-socjologiczny aspekt procesu kanonizacji tekstów biblijnych ${ }^{2}$, relacja dłuższego kanonu ST do kanonu krótszego w przekazie historycznym ${ }^{3}$, Pismo św. i autorytatywna tradycja $^{4}$, zakres interpretacji wewnątrzbiblijnej itp., które nadal są przedmiotem dyskusji naukowych i kontrowersji teologicznych.

Dotychczasowe opracowania form interpretacji Biblii w okresie międzytestamentalnym pokrywają się $\mathrm{w}$ zasadzie $\mathrm{z}$ klasyfikacją midraszów, która też nie jest zadówalająca ${ }^{5}$. Dochodzi do tego fakt, że formy interpretacji Biblii okresu międzytestamentalnego, tj. od poezątiu II w. przed Chr. do końca I w. po Chr., sprowadza się do midraszów rabinistycznych, które pochodzą z epoki późniejszej. Tak postąpił np. P. Weimar w swym skądinąd pionierskim szkicu pt.

1 Por. J. Bonsirven, Exégèse rabbinique et exégèse paulinienne, Paris 1939; O. Betz, Offenbarung und Schriftforschung in der Qumransekte, Tübingen 1960 .

2 Por. np. B. S. Childs, The Exegetical Significance of Canon for the Study of the Old Testament, w: Congress Volume Götingen 1977 (Suppl. to VT 29), Leiden 1978, 66-80; R. P. Carro1, Canonical Criticism: A Recent Trend in Biblical Studies?, ExpTim 92 (1980) 73-78; H. Cazelles, The Canonical Approach to Torah and Prophets, „Journal for the Study of the Old Testament" 16 (1980) 28-31; J. A. S a n ders, Canon and Community. A Guide to Canonical Criticism, Philadelphia 1984.

3 Por. B. S. Childs, Introduction to the Old Testament as Scripture, Philadelphia 1979; J. Golding a y, Approaches to Old Testament Interpretation, Dovners Grove 1981; Scripture in Jewish and Christian Traditions. Authority, Interpretation, Relevance, ed. F. G. Greenspahn, Nashville 1982.

${ }^{4}$ Por. K. He cker, Tradition und Originalität in der altorientalischen Literatur, "Acta Orientalia" 45 (1977) 245-258; Tradition and Theology in the Old Testament, ed. D. A. Knicht, Philadelphia 1977; B. W. Anderson, Tradition and Scripture in the Community of Faith, „Journal of Biblical Literature" 100 (1981) 5-21.

5 Por. R. Le Déaut, A propos d'une définition du midrash, „Biblica" 50 (1969) 395-413. 
Formy literatury wczesnożydowskiej ${ }^{6}$. Biorąc pod uwagę aspekt literacki, wydziela on trzy formy midraszu: egzeretyczny, homiletyczny i narracyjny, osobno traktując pešer z Kumran.

W świetle aktualnych teorii interpretacji Pisma św. sprowadzanie starożytnej interpretacji żydowskiej tekstów biblijnych do midraszu rabinistycznego okazuje się jednak zbyt uproszczone i nieadekwatne, gdyż w niewystarczającym stopniu bierze pod uwage Sitz im Le'ben interpretacji Biblii w okresie międzytestamentalnym oraz jej własne założenia hermeneutyczne.

Teoretycznie interpretacja Pisma św. obejmuje trzy fazy: explicatio, czyli egzegezę, meditatio, czyli teologię i applicatio, czyli decyzję, praktyke życiową, żywą tradycję ${ }^{7}$. Te trzy fazy odpowiadają, w jakiś sposób, trzem warstwom struktury tekstu w ujęciu P. Ricoeura ${ }^{8}$, który odróżnia warstwę struktur wypowiedzi, warstwę struktur kulturowych lub kodów i warstwę struktur głębokich. Trójdzielny podział midraszu na midrasz egzegetyczny, homiletyczny i narracyjny ma u podstaw wspomniane trzy fazy interpretacji Biblii i w jakiś sposób ich Sitz im Leben: szkołę, kult i pobożność prywatną. Ale dzisiaj wiadomo, że proces interpretacji Biblii, czy mówiąc ogólniej jakiegokolwiek tekstu, nie ma charakteru linearnego, lecz przybiera charakter tzw. „kręgu hermeneutycznego". Nie ma zatem czystych form wyjaśniania, medytacji czy zastosowania. Istnieje bowiem ich wzajemne uwarunkowanie: praktyka mająca formę żywej tradycji wpływa na egzegezę i ujęcia teologiczne, egzegeza opiera się na założeniach teologicznych itd. Również istnieje wzajemna zależność trzech zasadniczych środowisk interpretacji tekstów natchnionych, bo prywatna pobożność znajduje odbicie w kulcie, kult wpływa na szkołę itd. Zatem określenie form interpretacji w okresie międzytestamentalnym, kiedy dopiero krystalizuje się tradycja egzegetyczna, nie może dokonywać się a priori, w oparciu o teoretyczny schemat, lecz musi oprzeć się na analizie materiałów, w których należy brać pod uwagę ich konkretne Sitz im Leben i takie, a nie inne założenia hermeneutyczne.

\section{PRÓBA KLASYFIKACJI FORM INTERPRETACJI WEWNAZTRZBIBLIJNEJ}

Formy interpretacji Biblii okresu międzytestamentalnego organicznie wiąża się z formami interpretacji wewnątrzbiblijnej. W wielu wypadkach trudno nawet rozstrzjgnąć, czy chodzi o interpretację

${ }^{6}$ Formen frühjüdischer Literatur, w: Literatur und Religion des Frühjudentums, hrsg. J. Maier, J. Schreiner, Würzburg 1973, 123162.

7 Por. J. Sandys-Wunsch, On the Theory and Practice of Biblical Interpretation, JSOT 3 (1977) $66-75$.

8 Interpretation Theory: Discourse and the Surplus of Meaning, Fort Worth 1976, 92-94. 
wewnątrzbiblijną czy pozabiblijna, a to ze względu na niezbyt jasne rozgraniczanie w starożytnym judaizmie ksiąg kanonicznych od ksiąg niekanonicznych. Dlatego o interpretacji wewnątrzbiblijnej w ścisłym znaczeniu można mówić dopiero z pozycji przyjętego później kanonu rabinistycznego lub chrześcijańskiego.

Proces interpretacji ksiąg Starego Testamentu łączy się z samym ich początkiem. Wśród uczonych toczą się jednak dyskusje, jakie było główne środowisko powstawania ksiąg świętych oraz jakie czynniki historyczno-socjologiczne wpływały na uznanie pewnych tekstów za święte i niezmienne. Według niektórych egzegetów funkcja normatywna była glównym motorem reinterpretacji i kanonizacji tel:stów biblijnych ${ }^{9}$. Inni uwydatniają funkcję kultową tekstów jako główny czynnik ksształtujący kanon Pisma św. ${ }^{10}$. A Lemaire ${ }^{11}$ wysunął ostatnio hipotezę, że szkoła była głównym środowiskiem przekazywania dawnych tekstów biblijnych, wybierania tych tekstów do antologii i układania ich $\mathrm{w}$ obowiązującą całość dla następnych pokoleń.

Niezależnie od dyskusji na temat głównego środowiska wyłaniania się kanonu Starego Testamentu, badania dotyczące powstawania Biblii dowodzą, że przed niewolą babilońską forma tekstów pisanych wynurzała się przeważnie z tradycji religijnych, a od niewoli babilońskiej na powstanie literatury biblijnej w dużej mierze wpływała forma już istniejących ksiąg świętych ${ }^{12}$. Dlatego reinterpretacja ma miejsce $\mathrm{w}$ tekstach prawnych, homiletycznych, prorockich (np. Jr 23, 5-6 i $32,14-26)$ i w psalmach.

Po niewoli babilońskiej można wyróżnić trzy sposoby interpretacji wewnątrzbiblijnej: kanonizacja tekstów traktowanych jako słowo Boże przeznaczonych do czytania dla wspólnoty religijnej, reinterpretacja tekstów z Tory i Proroków oraz porządkowanie różnych tradycji w jedność. Według G. T. Shepparda ${ }^{13}$ czytaniem tekstów

9 Por. np. M. G. Kline, The Structure of Biblical Autority, Grand Kapids 1975; S. Leiman, The Canonization of Hebrew Scripture; the Talmudic and Midrashic Evidence, Hamden 1976.

${ }_{10}$ Por. np. G. OOstborn, Cult and Canon. A Study in the Canonization of the Old Testament, Uppsala 1950; E. J a cob, Principe canonique et formation de l'Ancien Testament, w: Congress Volume Edinburgh 1974 (Suppl. to VT 28), Leiden 1975, 101-112.

${ }_{11}$ Les écoles et la formation de la Bible dans l'Ancien Israël (Orbis Biblicus et Orientalis 39), Fribourg 1981.

12 Por. P. Grelot, Tradycja zródtem i kolebka Pisma św., "Concilium" 2 (1966-67) 577-690; M. M c N a mar a, Intertestamental Literature, Wilmington 1983, 19-43.

13 Canonization: Hearing the Voice of the Same God through Historically Dissimilar Tradition, "Interpretation" 36 (1982) 21-31. Por. także M. F is h bane, Torah and Tradition, w: Tradition and Theology in the Old Testament, ed. D. A. Knight, Philadelphia 1977, 27j-30j; tenże, Revelation and Tradition. Aspects of Inner-Biblical Exegesis, JBL 99 (1980) $343-361$. 
kanonicznych i porządkowaniem różnych tradycji w jednośé po niewoli babilońskiej sterowały trzy zasady hermeneutyczne: midrasz antologiczny, redakcja świadoma procesu kanonizacji oraz tematyzacja. Przez midrasz antologiczny rozumie on metodę wtórnego używania zdań lub charakterystycznych słów ze znanych tekstów biblijnych do ,tworzenia mozaiki instrukcji na dany temat". Druga zasada, reinterpretacja tekstów z Tory i Proroków pslega na tym, że redaktorzy ksiąg świętych odnosili jedną księgę do drugiej albo część księgi do innej księgi kanonicznej lub zbioru ksiąg kanonicznych. Tematyzacja natomiast polegała na tym, że oddzielone historycznie tradycje łączono wokół głównych grup tematycznych; w grupie Tory umieszczano instrukcje w stylu szkoły deuteronomistycznej lub kapłańskiej, w grupie Proroków gromadzono wszystko, co nosiło na sobie znamię „obietnicy”, a w grupie Pism (Ketubim) mądrość pełniła funkcję przewodnika życia, dlatego różne symbole mądrościowe z Tory i Proroków odczytywano w konkretnych sytuacjach życiowych.

Porządkowaniem i wyjaśnianiem tradycyjnego materiału zajmowali się pisarze (soferim), którzy stanowili odrębną grupę od szkoły deuteronomistycznej, kapłańskiej i mądrościowej, chociaż ich działalność zazębiała się $\mathbf{z}$ działalnością mędrców. Byli to przeważnie lewici, uważani za następców proroków (por. 2 Krn 24, 30, gdzie autor na miejsce „proroków” daje „lewitów”). Tak więc już w Biblii hebrajskiej wyłania się świadomość egzegetyczna, ale tradycja egzegetyczna nie występuje tu jako paralelna pod względem autorytetu do objawienia Bożego ani też nie pomniejsza objawienia, lecz stanowi sposób przekazu objawienia.

Świadomość egzegetyczna jako forma przekazu objawienia treści wiary starotestamentalnej jeszcze bardziej jest rozwinięta i wyraźniejsza w Septuagincie. Dzisiaj każdy przekład Pisma św. uważa się za formę jego interpretacji ${ }^{14}$. Ale badacze Septuaginty coraz częściej stwierdzają, że nie jest ona zwykłym przekładem tekstu hebrajskiego ST, ale świadomą interpretacją Tory jako Prawa (Nomos) dla wspólnoty $\dot{z} y d o w s k i e j ~ \dot{z y j a ̨ c e j ~ w ~ k u I t u r z e ~ g r e c k i e j, ~ a ~ d a l e j ~ t a k i m ~}$ przekładem, uporządkowaniem i pewną transpozycją Proroków i Pism, aby Biblia grecka stanowiła pełny przekaz objawienia Bożego przedchrześcijańskiego otwartego na wartości kultury hellenistycznej. Funkcję interpretacyjną objawienia Bəżego w Biblii greckiej pełnią zwłaszcza teksty deuterokanoniczne, jak np. Księga Syracha lub Modlitwa Mardocheusza i Estery.

R. Le Déaut, w znakomitym studium na temat charakteru Septuaginty stwierdza: „Proces, który wyjaśnia funkcję ST, był więc żywotny również w konstytuowaniu się Biblii greckiej. D. Barthélemy

14 Por. C. R. T a ber, Translation as Interpretation, „Interpretation" 32 (1978) $130-143$. 
udowodnił twierdzenie, że Stary Testament dojrzał w Aleksandrii, uzyskując tam swą ostateczną, zamierzoną przez Boga formę, z którą bezpośrednio wiąże się orędzie NT". ${ }^{15}$.

\section{FORMY INTERPRETACJI BIBLII W STAROŻYTNYM KULCIE ŻYDOWSKIM}

Kult żydowski stanowił podstawowe środowisko przekazu i interpretacji ksiąg świętych. Liturgia spełniała dwie zasadnicze funkcje interpretacyjne Biblii: niekończący się proces poszulkiwań tożsamości wspólnoty religijnej w oparciu o objawiony model w Piśmie św. (czytanie Pisma św., homilie, targumy) oraz wcielanie objawionej tożsamości we wspólnocie kultowej (rytuał, modlitwy, medytacje dochodzące do doświadczeń mistycznych).

W juciaizmie oficjalnym okresu międzytestamentalne o istniały dwa odrębne środowiska kultowe: kult świątynny i liturgia synagogalna. Stąd np. S. Sandmel ${ }^{16}$ wyróżnia w tym okresie dwie formy judaizmu: julaizm świątynny i judaizm synagozalny. Formy interpretacji Biblii w ramach kultu świątynnego miaìy charakter autorytatywny, dlatego w różnych środowiskach przechodziły do kanonu biblijnego, stanowiąc element interpretacji wewnątrzbiblijnej. Natomiast formy interpretacji Biblii w ramach liturgii synagogalnej miały charakter masowy, ludowy, dlatego stanowily materiał literatury pozabiblijnej, zwłaszcza późniejszej literatury rabinistycznej.

Jeśli chodzi o synagoge, to nie rozstrzygnięto dotychczas, jakie było jej pierwszoplanowe przeznaczenie: kultowe czy do nauczania. Przypuszcza się, że synagoga jako instytucja powstała najpierw w diasporze na wspólne modlitwy, a stamtąd przeszła do Palestyny. Wiadomo natomiast, że w czasach Chrystusa liturgia synagogalna ściśle była powiązana $z$ liturgią świątynną.

a) Czytanie Pisma świętego

Wprowadzony przez Ezdrasza zwyczaj publicznego czytania Tory w oprawie liturgicznej, który rozszerzono później także na inne części Biblii, miał charakter interpretacji tekstów świętych. Księga Nehemiasza 8, 8 stwierdza: „Czytano więc z tej księgi, księgi Prawa Bożego, dobitnie, $\mathrm{z}$ dodaniem objaśnienia, tak że lud rozumiał czytanie". Gdy później dobierano do czytania fragmenty z Tory i Proroków, obowiązywała zasada interpretacji Biblii przez Biblię.

Francuski pisarz i poeta Paul Claudel, odprawiając w listopadzie 1903 r. rekolekcje u Księży Misjonarzy w Paryżu, zanotował w swo-

15 Septuaginta - Biblia zapoznana, RBL 37 (1984) 454-470. Por. także R. L e Déa u t, La Septante, un Targum?, w: Etudes sur le Judaïsme hellénistique (Lectio divina 119), Paris 1984, 149-195.

16 Judaism and Christian Beginnings, New York 1978. 
im dzienniku charakterystyczne zdanie na temat czytania Staress Testamentu: „Hebrajski ma jedynie spółgłoski; tekst oczekuje inspiracji, tchnienia, jakie daje mu duch, który pozwala słowom byé wymawianymi"17. Wypowiedź tę w teologii trzeba traktować oczywiśzi: cum licentia poetica, ale i dzisiaj Biblię porównuje sę do partytury muzycznej, którą należy ożywiać poprzez ciągle nowe odczytywanie ${ }^{18}$. Był tego świadom Filon z Aleksandrii, kiedy pisze o terapeutach, że crytali Pismo święte w przekonaniu, że słowa pisane są symbolem ukrytej prawdy, która zostaje objawiona dopiero przy głębokirn studium. ${ }^{19}$.

Instytucja czytania Biblii w świątyni i synagodze ma związek z trudnością dostępu do ksiąg świętych w starożytności. W czasach Ezdrasza i Nehemiasza lud nie miał żadnej księgi (Neh 8, 1-8). W czasach machabejskich odpisy „Księgi Przymierza” i „Księgi Prawa" były w domach prywatnych, ale nie wiemy, co w nich się znajdowało. Według 2 Mch 2, 14-15 Juda Machabeusz zorganizowa! w Jerozolimie bibliotekę, żeby uchronić księgi święte przed zagłada. W okresie międzytestamentalnym oprócz świątyni i synagogi księgi święte były więc w posiadaniu osób prywatnych, ale byli nimi przeważnie nauczyciele, a lud znał Pismo święte tylko z publiczneso czytania. Biblia była znana na ogól nie z patrzenia w tekst i kontekst, lecz ze.słuchảnia.

Początkowo teksty przeznaczone do czytań były dobierane. Cykliczne czytanie Pięcioksięgu (seder) i Proroków (haftara) jako instytucja żydowska weszło $\mathrm{w}$ praktykę na terenie Palestyny dopiero w II po Chr., ale jako zwyczaj regionalny lub grupowy sięga prawdopodobnie czasów przedchrześcijańskich.

Według Miszny (Megilla 4, 1-4) każdy seder musiał obejmowáe przynajmniej 21 wierszy, które mogło czytać więcej osób, każda przynajmniej po trzy wiersze. W podziale na sedery brano pod uwage proporcje między wstępem i zakończeniem oraz diugość tekstu. Pięcioksiąg dzielono na ogół na jednostki dające jakąś całość tematyczną zarówno w trzyletnim cyklu czytań na terenie Palestyny, jak również w rocznym cyklu czytań w Babilonii. Natomiast haftary były krótsze i wyrwane z kontekstu. Haftara mogła zawierać 10 wierszy. Zwracano w niej główną uwagę na pierwszy wiersz nawiązujący jakimś słowem lub wyrażeniem do sederu i na zakończenie ${ }^{20}$.

b) Przekaz Pisma świętego w homiliach

Nie znamy homilii związanych $z$ czytaniem Biblii w świątyni. Przypuszczalnie w związku z Dniem Pojednania arcykapłana wygła-

17 Dziennik 1904-19j5, przeł. z j. fr. J. Rogoziński, Warszawa 1977, 13. 463.

18 Por. R. Le Déa ut, Septuaginta - Biblia zapoznana, RBL 37 (1984)

19 De vita contemplativa 28.

$20 \mathrm{Na}$ ten temat zob. D. Patte, Early Jewish Hermeneutic in Palestine (Dissertation Series SBL 22), Missoula 1975, 31-47. 
szał mowę, w której ukazywał działanie Boga w całej historii narodu wybranego oraz zachowanie się narodu wobec Boga. Nie wiadomo także, jak wyglądały homilie we wczesnej fazie rozwoju kultu synagogalnego. Prawdopodobnie były to mowy okolicznościowe, dlatego odbiegające formą i treścią od tekstów biblijnych, zwłaszcza w kulturze hellenistycznej.

Dzięki badaniom Jakuba Manna znamy natomiast strukturę homilii synagogalnych zachowanych $\mathrm{w}$ pismach rabinistycznych ${ }^{21}$. W pismach rabinistycznych zachowały się dwie formy wprowadzenia do homilii: jelammedenu i petichta (peticha). Przez dłuższy czas sądzono, że są to elementy formalne, nie mające związku z treścią homilii. Dopiero W. Bacher ${ }^{22}$ wykazal, że istniała specjalna forma homilii typu petichta, której celem było uwydatnienie łączności między trzema częściami Biblii (Torą, Prorokami i Pismami), tzn. że trzy części Biblii wyrażają to samo w różnych formach, że to są różne formy przekazu tej samej treści. Następnie Jakub Mann udokumentował, że wiersz otwierający homilię czyli petichta był zdeterminowany poprzez seder, ale brany spoza sederu, najczęściej z psalmu. Drugi typ homilii polegał na tym, że wierszem wprowadzającym była jakaś sentencja rabina zawierająca zagadnienie halachiczne (jelammendenu rabbenu - pozwólmy uczyć się naszym ojcom). W tym typie homilii kaznodzieja wykazywał, że nauczanie star̊szych jest zgodne z wszystrimi częściami Biblii. Celem tego rodzaju homilii było uwydatnienie lączności nie tylko między trzema częściami Biblii,-lecz także między Torą pisaną i Torą ustną, tj. nauczaniem rabinów.

$\mathrm{Z}$ analizy homilii synagogalnych, zachowanych $\mathrm{w}$ pismach rabinistycznych, J. Mann wyciąga następuje wnioski:

1) Żydzi uważali całe Pismo święte za jednakowo natchnione.

2) Szczególną uwagę zwracano na słowa i litery Biblii, a mniej. szą na tematy teologiczne wyrażone w Piśmie świętym.

3) Ciągłe wyjaśnianie jednego pisma przez inne pismo prowadziło do zamkniętego systemu znaków.

4) Uważano, że istnieje ścisła więź między Pismem świętym a Tradycją.

Te wnioski dotyczą judaizmu klasycznego, nie wcześniejszego niż koniec I w. po Chr., ale w jakiejś mierze odnoszą się do wcześniejszej interpretacji Biblii w kołach faryzejskich. Być może, iż tego rodzaju homilie były praktykowane $w$ synagogach palestyńskich juz w epoce przedchrześcijańskiej..

Homilie w synagogach posługujących się językiem greckim nawiązywały do reguł retoryki hellenistycznej. Homiliami synagogalnymi w świecie hellenistycznym zajmował się $\mathrm{H}$. Thyen, publikując na

21 The Bible as Read and Preached in the Old Synagoque, Vol. 1-2, Cincinnati $1940-1966$.

22 Lie Proömien in der alten jüdischen Homilie, Leipzig 1913. 
ten temat monografię w 1955 r. ${ }^{23}$ Zgromadził on materiał z różnych dzieł biblijnych i pozabiblijnych wykazując, że na styl homilii synagogalnej $\mathrm{w}$ świecie hellenistycznym znaczny wpływ wywierała diatryba stoicka. Przedmiotem rozważań był Pięcioksiąg. Ale teksty Pięcioksięgu czerpali kaznodzieje zasadniczo z testimoniów i interesowali się głównie postaciami biblijnymi. Homilie hellenistyczne mialy charakter pedagogiczny, budujący. Kaznodzieja szukał w ST świadectwa opieki Boga nad narodem izraelskim oraz praktycznych modeli różnych cnót.

\section{c) Targumy}

Targum to aramejski przekład i jednocześnie interpretacja czytań biblijnych. Tradycyjny pogląd odnoszący początek targumów do czasów Ezdrasza został zakwestionowany przez uczonych współczesnych ${ }^{24}$, ale targumy na pewno sięgają jednak epoki przedchrześcijańskiej. Świadcza o tym tradycje zachowane w Misznie oraz teksty aramejskie znalezione w Kumran (tg Księgi Hioba i fragment targumu do Kpł) ${ }^{25}$.

Targumy przekazane $\mathrm{w}$ formie pisemnej przez rabinów pochodzą z epoki późniejszej (od II w. po Chr.), ale zawierają materiał z okresu przed zburzeniem świątyni w $70 \mathrm{r}$. Targumy wywodza się $z$ trzech środowisk: ze szkoły, z prywatnej pobożności i z liturgii synagogalnej. Najważniejszym jednak środowiskiem, zwłaszcza jeśli chodzi o najstarszą warstwę targumu palestyńskiego do Pięcioksięgu, jest synagoga. Początkowo był to tekst przeznaczony do liturgii synagogalnej obok tekstu hebrajskiego. Później niemal wszystkie targumy przeszły rewizję i stylizację literacką w szkołach rabinistycznych; w średniowieczu miały już status dzieł czysto literackich.

Angielski znawca targumów P. S. Alexander ${ }^{26}$ dowodzi, że na pierwotną formę targumów wpływały następujące czynniki:

1) Targum był publicznie recytowany wobec zgromadzonych Żydów w synagodze.

2) Był on przeznaczony nie dla uczonych w Piśmie, lecz dla nieuezonych mas.

3) Celem targumu było przekazanie pełnego przekładu Pisma świętego.

23 Der Stil der jüdisch-hellenistischen Homilie, Göttingen 1955.

24 Por. M. M c Namara, The New Testament and the Palestinian Targum to the Pentateuch, Rome 1966, 39; D. Patte, dz. cyt., 49.

25 Por. ks. S. Mędala, Najstarsze targumy palestyńskie oraz ich znaczenie dla badań starożytnego judaizmu, "Przegląd Orientalistyczny" 91 (1974) $247-256$.

${ }_{26}$ The Targumim and the Rabbinic Rules for the Delivery of the Targum, W: Congress Volume Salamanca 1983 (Suppl. to VT 36), Leiden 1984 14-28. 
4) Równocześnie obejmował on wyjaśnienie Biblii i rozwiązanie nasuwających się problemów.

5) Jako tekst popularny i liturgiczny, targum we wczesnym stadium nie mial charakteru standardowego i nie był poddany pod bezpośrednią kontrolę rabinów.

Jako naczelną zasadę interpretacyjną targumiści stosowali interpretację Biblii przez Biblię. Targumy stanowią aktualizację i przystosowanie Biblii do etosu wspólnoty żydowskiej zbierającej się w synagodze na modlitwę. Wspólnota żydowska w synagodze rodziła się z czytania i. rozważania Biblii, identyfikując się z ludem Bożym tam opisanym.

Ponieważ targumiści traktowali historię świętą jako zamknięta, a Pismo święte jako całość objawienia, harmonizowali teksty biblijne i nadawali im jednoznaczny sens teologiczny. W tym celu stosowali różne techniki egzegetyczne, jak: opatrywanie słów hebrajskich odpowiednią wokalizacją, dzielenie zdań i słów, przestawianie liter w odwrotnej kolejności (tzw. metoda ẩoaš), posługiwanie się gematrią, uzupełnianie zdań, żeby nie było niedomówien, teksty trudne wyjaśniano prostszymi síormułowaniami, dokonywano identyfikacji miejscowości i wprowadzano dokładne daty, w osobach biblijnych ukazywano typy moralne wierzących Żydów itp. Z praktyki targumistów sformułowano później 32 reguły (middot) haggadycznej interpretacji Pisma świętego, które tradycja talmudyczna przypisuje raíbiemu Eliezerowi ben Jose ha-Gelili z czasów Bar Kochby. Są to analogiczne reguły do 7 reguły Hillela i 13 reguł Jiszmaela, które wypracowano w szkołach rabinistycznych do interpretacji tradycji halachicznych ${ }^{27}$.

\section{d) Rytuat}

Rytuał w świątyni jerozolimskiej stanowił konkretny przekaz przepisów biblijnych w określonych warunkach historycznych. Zasadnicza jego struktura w okresie międzytest:mentalnym była niezmienna, dlatego dawała wspólnocie kultowej przeświadczenie o wcieleniu objawionego modelu w konkretnym czasie i miejscu. Wcieleniem modelu biblijnego, przynajmniej w oczach ludu, była instytucja kapłańska ${ }^{23}$.

Tego przeświadczenia nie dawał wspólnocie żydowskiej rytuał synagogalny, który był wprawdzie powiązany z rytuałem świątynnym, ale bez ofiar i w zasadzie bez urzędowego kapłaństwa. Dlatego w li-

27 Pelne omówienie tych reguł wraz $\mathrm{z}$ odnośną bibliografią podaje H. L. Strack, G. Stemberger, Einleitung in Talmud und Midrasch, 7 Aufl., München 1982, 23-40.

ء $\mathrm{O}$ modelu kuiturowym społeczeństwa palestyńskiego $\mathrm{W}$ czasach Chrystusa traktuje B. J. Malina, The New Testament World. Insights from Cultural Anthropology, Atlanta 1981. 
turgii synagog̨lnej eksponowano głównie Słowo Boże, a mniej działanie Boże. Doszło nawet do tego, że po 70 r., kiedy w judaizmie została jedynie insty tucja synagogalna, zbawcze działanie Boże odnoszono do przeszłości i do przyszłości, a nie dostrzegano zbawczego działania Boga w aktualnej historii.

e) Modlitwa

W liturgii świątynnej i synagogalnej Pismo święte stanowiło nie tylko przedmiot rozważań, lecz także material do modiitw. W Hulis miało miejsce nie tylko wspominanie, lecz także uobecnianie działania Bożego. Actio Dei łączyla się z reactio ludu.

Do czasów talmudycznych w liturgii żydowskiej glównymi modlitwami były psalmy biblijne. Przypuszcza się, że pięcioczę́sinwy układ Psałterza wiąże się już z systematycznym czytaniem Pıęcioksięgu ${ }^{29}$.

W okresie międzytestamentalnym powstało wiele innych modlitw przeznaczonych dla celów kultowych lub dla pobożności prywatnej. Niektóre z nich weszìy do Biblii greckiej (Septuaginty), a inne przeszły do późniejszego modlitewnika żydowskiego Siddur haš-šalem). Nie wiadomo jedak, jaką I̊nnkcję spełniały te modlitwy w ówczesnej liturgii świątynnej.

Do modlitw, które weszły do kanonu greckiego należą: modlitwa Syracha o wyzwolenie Izraela (Syr 36, 1-17), lamentacja wspólnotowa z Dn 9, 4-19 i Bar 1, 14-3, 8; modlitwa Azariasza (gr. Dn 3, 26-45), lamentacja wspólnotowa z Księgi Judyty (r. 9), modlitwa Mardocheusza i Estery (w Wulgacie rr. 13-14; w gr. 4, 17a-17z), pieśń trzech młodzieńców (gr. Dn 3,51-90) i modlitwa Salomona o mądrość (Mdr 9) ${ }^{30}$.

Modlitwami, które powstały w tym czasie, ale nie weszły do kanonu Pisma świętego są: Modlitwa Manassesa, modlitwa arcykapłana Szymona (3 Mch 2, 2-20), modlitwa kaplana Eleazara (3 Mch 6, 2-15), prototyp modlitwy Szemoneh esreh w hebrajskim tekście Syr 51, 12, Liturgia światel niebiańskich, psalmy i kantyki w tekstach kumrańskich oraz Psalmy Salomona. Na szczególną uwagę zasługuje „Liturgia świateł niebiańskich" (4QDibHama), którą odkryto w Kumran na kilku fragmentach $\mathrm{z}$ trzech kopii. Najstarszy rękopis pochodzi z ok. 150 r. przed Chr. Wczesna data rękopisu oraz brak elementów sekciarskich $\mathrm{w}$ modlitwie wskazują, że mamy do czynienia z dziełem chasydejczyków przedkumrańskich. Reprezentuje to dzieło prawdopodobnie liturgię kapłańską Sadokitów. Dzieło składa się z modlitw i hymnów opatrzonych rubrykami. Jedna, rubryka mówi

29 Por. A. Arens, Die Psalmen im Gottesdienst des Alten Bundes, Trier $1961,19 \overline{5}-210$.

${ }^{30} \mathrm{Na}$ temat modlitw żydowskich okresu międzytestamentalnego zob. M. M c N a mara, Intertestamental Literature, 165-210. 
o czwartym dniu tygodnia (środa), a inna o „hymnach na dzień szabatu". Przed modlitwami na sobotę znajduje się długa modlitwa pokutna, przeznaczona prawdopodobnie na piątek. Dzieło to zawierało przypuszczalnie modlitwy na każdy dzień tygodnia, wspominając najważniejsze wydarzenia z historii świętej.

Z liturgii synagogalnej wywodzą się następujące modlitwy judaizmu rabinistycznego: Szema Jisrael, którą w czasach NT recytowano (albo raczej czytano) w łączności z ofiarą tamid; Szemoneh esreh, stanowiąca zbiór podstawowych pojęć teologicznych ST; Keduszah, podejmująca i rozwijająca słowa aniołów z teofanii przy powołaniu Izajasza i Ezechiela, oraz Kaddisz, ułożona pierwotnie w języku aramejskim, zawierająca bliskie paralele $z$ "Modlitwą Pańską" ${ }^{31}$.

\section{INTERPRETACJA BIBLII W SZKOEACH}

W liturgii synagogalnej miały swe Sitz im Leben tradycje haggadyczne, które podawały zasady wiary żydowskiej. Natomiast w szkołach miały Sitz im Leben tradycje halachiczne, które podawały zasady postępowania. Podczas, gdy w synagogach przekazywano i uwydatniano głównie sens dogmatyczny Pisma świętego, w szkołach wyjaśniano prawa i przepisy biblijne w taki sposób, żeby ukazać wszystkie aspekty życia codziennego wspólnoty żydowskiej. To wyjaśnianie praw i przepisów bíblijnych nazywano ustną Torą, której faryzeusze przypisywali taki sam autorytet, jak Torze pisanej. W ten sposób objawienie Boże (tj. wolę Bożą) odkrywano nie tylko w Piśmie świętym, lecz także w kulturze współczesnej.

Halacha w znaczeniu obowiązującego obyczaju zrodziła się w narodzie żydowskim w czasach machabejskich. Po niewoli babilońskiej wspólnota żydowska miała charakter teokratyczny, w której arcykapłan, będący niejako zastępcą Boga, miał najwyższą władzę nad wspólnotą zarówno w sprawach duchowych, jak i materialnych (por. Ezdr 7, 25-27; Syr 50). Natomiast w czasach machabejskich teokracja przeobraziła się w nomokrację. Nastąpiło to $\mathrm{w}$ związku z ustabilizowaniem się Sanhedrynu jerozolimskiego jako najwyższego sądu żydowskiego. Odtąd ostateczne decyzje w sprawach doczesnych i duchowych wyrażały się nie w dekretach arcykapłana, lecz w Torze, którą Sanhedryn przyjmował jako powszechną drogę życia (halacha). Przez Torę rozumiano zarówno Biblię, jak i ustną tradycję ${ }^{\mathbf{8 2}}$.

$31 \mathrm{O}$ modlitwach judaizmu rabinistycznego zob. K. G. Kuhn, Achtzehgebet und Vaterunser und Reim, Tübingen 1950; J. H e ineman n, Frayer in the Talmud, New York 1977; ks. J. D rozd, Ojcze nasz. Modlitwa Pańska, według współczesnej egzegezy (Attende lectioni 9), Katowice 1983, 14-20; ks. N. M e n d e ki, Modlitwa, Osiemnastu błogosławieństw", RBL 37 (1984) 140-143.

82 Por. D. P a t te, dz. cyt., 87-93. 
Ustna tradycja stanowiła wynik przystosowania Tory do życia. To przystosowanie było konieczne nie tylko ze względu na zmieniające się warunki życia w ciagu wieków, lecz także dlatego, że wspólnota żydowska zaczęła traktować Pismo święte jako kodeks regulujący zarówno jej życie religijne, jak i cywilne. Tymczasem przepisy rytualne i prawa zawarte w Pięcioksięgu były niemożliwe do zachowania bez żywej tradycji kapłańskiej przekazującej-rytuał lub bez tradycji jurydycznej przechowywanej w etosie konkretnej społeczności życlowskiej. Dlatego ustną Torę, którą początkowo nazywano tradycja (kabalah lub micwah ziknim), traktowano od bardzo dawna zarówno jako uzupelnnienie Tory, jak również jako interpretację tej Tory w konkretnych sytuacjach życiowych.

Wśród uczonych toczy się jednak kontrowersja nad pochodzenicm ustnej Tory. W czasach Nowego Testamentu halacha była przekazywana $\mathrm{w}$ dwóch formach: $\mathrm{w}$ formie misznaickiej $\mathrm{i} \mathrm{w}$ formie midraszu. W formie misznaickiej halacha przekazywała nauki dawnych mistrzów, nie przytaczając na dowód tekstów biblijnych. Natomiast halacha $\mathrm{w}$ formie midraszu polegała na interpretacji $\mathrm{i}$ wykładaniu Tory pisanej. Problem polega na ustaleniu, która forma halachy jest starsza. J. Z. Lauterbach ${ }^{38}$ utrzymuje, że halacha w formie midraszu jest starsza, natomiast S. Zeitlin ${ }^{84}$, za którym opowiada się dzisiaj większość ekspertów starożytnego judaizmu dowodzi, że w czasach machabejskich, kiedy rodziła się halacha, naród żydowski był spoleczeństwem żywotnym, twórcą praw dyktowanych przez warunki historyczne, a nie tylko przez interpretację Tory.

Lauterbach i Zeitlin zgadzają się ze sobą w tym, że źródłem ustnej Tory były $z$ jednej strony tradycje i obyczaje żydowskie, a $\mathrm{z}$ drugiej strony interpretacja ksiąg świętych. Tak więc $\mathrm{z}$ jednej strony ustna Tora czyli halacha wywodziła się ze zwyczajów i praw żywotnej wspólnoty żydowskiej niezależnie od Biblii, a dopiero później była weryfikowana i uprawomocniona przez przytaczanie tekstów biblijnych. $\mathrm{Z}$ drugiej strony ustna Tora wyrastała także $\mathrm{z}$ interpretacji Biblii $w$ formie midraszu. W czasach Nowego Testamentu ustna Tora, niezależnie od jej pochodzenia, była uznawana przez faryzeuszów za objawioną przez Boga. Hillelowi przypisuje się sformulowanie, które mówi o dwóch Torach, żeby uwydatnić autorytet obydwóch źródeł nauki religijnej (por. Szab 31a).

Kontrowersja między saduceuszami i faryzeuszami na temat autorytetu halachy wskazuje na dwa różne podejścia hermeneutyczne do Pisma świętego ${ }^{35}$. Saduceusze byli starszym stronnictwem religij-

ss W art. Midrash and Mishnah opublikowanym w ,Jewish Quartely Review" 1915-16, przedrukowanym w dziele Rabbinic Essays, Cincinnati $1951,163-256$.

\$4 Halaka: Introduction fo Tannaic Jurisprudence, „Jewish Quarterly Review" 39 (1948-49) $1-40$.

s5 Por. D. P a t te, dz. cyt., 93-99. 
no-politycznym niż faryzeusze. Przed pojawieniem się faryzeuszów, od czasów Ezdrasza, Pismo święte uznawano za absolutny autorytet. Ale autorytet Tory wynikał nie z niej samej, lecz z pozytywnego zobowiązania się Izraela do wypełniania praw Mojżeszowych. To zobowiązanie rozciągano na wszystkie pokolenia. Saduceusze, będąc przywódcami ludu z klasy kapłańskiej, mieli także własne zwyczaje i byli ich przekazicielami. Co więcej, wydawali dekrety i przepisy, których zachowanie uważali za obowiązujące. Ale tym prawom nie nadawali autorytetu Bożego.

Natomiast faryzeusze, którzy byli innowatorami w rozumieniu Prawa, przyjmowali współmierność Tory z życiem codziennym. „Tora obejmuje wszystiko i wszystko wyraża (Lauterbach). W swej interpretacji Tory nis wychodzili z przysięgi, zobowiązania lub przymierza, lecz z przekonania o Boskim pochodzeniu Tory. Torę uważali za dar Boga dla człowieka, żeby mógł dobrze postępować i zbliżać się do Boga. Według Lauterbacha faryzeusze nie byli niewolnikami Prawa, lecz jego panami i nauczycielami.

Przekonanie, że Tora jest darem od Boga i jest współmierna z życiem stanowilo dwie podstawowe zasady hermeneutyczne faryzeuszów w interpretacji Biblii. Dla faryzeuszów Pismo święte stanowiło ogólne objawienie Boże, które należy interpretować $w$ świetle nauki prorockiej i tradycji. Interpretacja Biblii $\mathrm{w}$ ich przekonaniu nie była wprowadzaniem nowych treści, lecz właściwym rozumieniem Tory. Aby Tora mogła być współmierna z życiem włączano do niej tradycyjne zwyczaje i prawa; które stanowiły dziedzictwo Judejczyków. Te zwyczaje i prawa przyjmowano bądź celem uzupełnienia brakujących przepisów w Pismie świętym, bądź w celu dostosowania się do nowych sytuacji życiowych. Nie przyjmowano jednak na ślepo jakichkolwiek tradycji jako Tory ustnej, chociaż nie wiemy, jakim: kryteriami kierowali się faryzeusze u swych początków, gdy przyjmowali pewne zwyczaje i przepisy jako mające Boski autorytet: Natomiast od czasów Hillela wprowadzono reguły uzgadniania Tory ustnej z Torą pisaną; są to tzw. siedem reguł Hillela (middot), a potem 13 reguł Jiszmaela oraz wyróżnienie pięciu form ustnej tradycji, halachot (reguły życia), gezerot (dekrety), takkanot (przepisy), minhagin (zwyczaje) i sejag (ogrodzenie Tory).

Gezerah to rozporządzenie, dekret promulgowany na mocy autorytetu Sanhedrynu albo jego przewodniczącego. Takkanah to nowy przepis, ale wyprowadzony $\mathrm{z}$ tekstu biblijnego (jednym $\mathrm{z}$ najsłynniejszych przepisów tego rodzaju jest tzw. prosbul Hillela). Minhagin to zwyczaje i prawa regionalne (np. Palestyny, Babilonii, Jerozolimy) lub niektórych grup społecznych (np. pewnych rodów, pobożnych ludzi, uczonych, ludu itp.). Chociaż zwyczaje miały charakter zobowiązujący dla poszczególnych grup, nie traktowano ich jako Tory ustnej pochodzenia Bożego w myśl zasady, że Bóg jest jeden i Jego prawo ma obowiązywać jednakowo wszystkich Iudzi. 
Ustna Tora była traktowana jako żywa tradycja, podatna na rozwój, rozszerzanie, dostosowywanie, korektę i aktualizację. Następowało to przez:

1) Włączanie nowych halachot, gezerot i takkanot;

2) Promulgację nowych halachot wyprowadzonych $z$ interpretacji Tory pisanej typu midraszowego;

3) Autorytatywną interpretację halachy; był to rodzaj midraszu na temat Tory ustnej.

Łączność między Torą ustną a Torą pisaną opierała się na dogmacie judaizmu tannaickiego, że naród izraelski został wybrany dla uświęcenia Imienia Bożego. Uświęcenie Imienia Bożego oznaczało oddawanie Bogu czci, uznawanie Jego obecności i działania oraz pobudzanie innych do błogosławienia Boga. Wypełnianie przykazań Bożych uznawano za szczególny obowiązek ze względu na innych ludzi, żeby błogosławili Boga i uznawali Jego obecność. Wychodząc z tego dogmatu rabini uważali za swój obowiązek poprawiać Pismo święte zgodnie $\mathrm{z}$ wymogami kultury. Poprawianie Tory miało uświęcać Imię Boże pozytywnie lub negatywnie. Pozytywne uświęcanie Imienia Bożego miało miejsce wtedy, gdy wprowadzano przepisy (takkanot) ułatwiające wypełnianie przykazań Bożych, zwłaszcza przykazania miłości. Negatywne uświęcanie Imienia Bożego polegało na przeciwdziałaniu Jego profanacji. W tym celu łagodzono lub znoszono przepisy, aby zapobiegać przed ich przekraczaniem ${ }^{\mathbf{3 6}}$.

Inna forma ustnej tradycji szła w odwrotnym kierunku; zamiast łagodzenia przepisów Prawa, intensyfikowano nakazy i przepisy, mnożono przykazania, żeby stworzyć tzw. „ogrodzenie Tory” ( $s^{e} j a g$ ). $\mathrm{Z}$ biegiem czasu wprowadzono tyle przepisów, że rabbi Akiba mógł powiedzieć: „Tradycja (masoret) stanowi ogrodzenie Tory" (Abot 3, 13). Ogrodzenie Tory miało prowadzić do uświęcenia Imienia Bożego $\mathrm{w}$ łonie narodu żydowskiego. Chodziło w tym wypadku o odseparowanie żydów od pogan. W praktyce lagodzenia przepisów, Torę traktowano jako system odniesienia do pogan, a w praktyce mnożenia przepisów Torę traktowano jako system odniesienia do narodu $\dot{z} y-$ dowskiego. Mądrość faryzeuszów, a potem tannaitów polegała na zachowaniu równowagi między tymi dwoma biegunami, żeby $\mathrm{z}$ jednej strony utrzymać pojęcie wybrania Izraela, a $z$ drugiej strony dostosować się do obiektywnych wartości w zastanej kulturze i wypełniać posłannictwo misyjne w stosunku do wszystkich ludzi. Ustawiczne kontrowersje między szkołami rabinistycznymi (zwłaszcza między szkołą Hillela i Szamaja) to kontrowersje między judaizmem konserwatywnym i liberalnym ${ }^{37}$.

86 Por. tenże, 107-109.

37 Por. tenże, 122-127; E. E. U r b a c h, The Sages. Their Concepts and Beliefs, Jerusalem 1979, 286-314. 814-825. 


\section{FORMY INTERPRETACJI BIBLII MAJĄCE SITZ IM LEBEN W POBOŻNOSCI PRYWATNEJ}

Pobożność prywatna, zarówno wspólnotowa jak i indywidualna, stanowi przedłużenie rozważania Pisma Swiętego w kulcie świątynnym i synagogalnym, jak również $\mathrm{w}$ szkole $\mathrm{w}$ konkretnych warunkach życiowych. Nauczyciele żydowscy podkreślali, że praktyka życiowa musi poprzedzać studium Pisma świętego, a studium ma służyć po to, żeby żyć Prawem Bożym. Nic więc dziwnego, że pobożność prywatna stanowi bardzo ważne podłoże rozumienia i interpretacji Biblii $w$ okresie międzytestamentalnym. Filon $z$ Aleksandrii, mówiąc o zgłębianiu tekstów świętych przez terapeutów wyjaśnia, że w każdym domu mają specjalne miejsce święte, gdżie przez sześć dni w tygodniu kontemplują prawa, wypowiedzi proroków, hymny i inne pisma, które dają wychowanie oraz doskonalą wiedzę i pobożność. W siódmym dniu zbierają się razem, a starszy $z$ nich wygłasza mowę na jakiś temat Pisma świętego lub rozwiązuje trudność podsuniętą przez kogoś z zebranych. Alegoryczne wyjaśnienie wydobywa wewnętrzny sens tekstów świętych ${ }^{\mathbf{8 8}}$.

\section{a) Apokryfy Starego Testamentu a Biblia}

-Niemal wszystkie apokryfy Starego Testamentu, zarówno palestyńskie jak i hellenistyczne, są owocem pobożności prywatnej. Były one pisane zasadniczo po to, aby ustalać własną tożsamość w stosun$\mathrm{ku}$ do grup rywalizujących lub do judaizmu świątynnego oraz w stosunku do Boga. Tradycyjny podział apokryfów ST podkreśla ich ścisłą łączność $z$ księgami świętymi, ale mniej uwydatnia ich charakter literacki. Aktualnie istnieje tendencja, żeby apokryfy ST dzielić według ich charakteru literackiego: apokalipsy, testamenty, midraszowe poszerzenia ST itp. ${ }^{89}$

Apokalipsy wywodzą się z kół żydowskich, które oprócz uczestnictwa $w$ kulcie świątynnym i liturgii synagogalnej, zgłębiały teksty święte na specjalnych zebraniach lub indywidualnie. Dlatego apokaliptyka jest nasycona Biblią. W apokalipsach interpretacja Biblii ma formę midraszu antologicznego i midraszu strukturalnego. Charakterystycznym elementem apokaliptyki są wizje, które mają charakter bądź ekstatyczny bądź wtórny. W wizjach ekstatycznych spotykamy głównie midrasz strukturalny, a wizjach wtórnych przeważnie midrasz antologiczny. Midrasz antologiczny w apokaliptyce stanowi

${ }^{38}$ Por. Quod omnis probus liber 80-82; De vita contemplativa 25-31. 75-78. Na temat życia zgodnego $\mathrm{z}$ nakazami Prawa jako podstawowej reguły hermeneutycznej $\mathrm{w}$ judaizmie zob. F. Manns, Vivre de l'Écriture pour mieux la comprendre. Un aspect de l'herméneutique juive et judéo-chrétienne, „Studii Biblici Franciscani Liber Annuus” 28 (1978) 45-59.

${ }^{39}$ Por. The "Old Testament Pseudepigrapha. Vol. 1. Apocalyptic Literature and Testaments, ed. J. H. Charlesworth, Garden City 1983. 
przedłużenie stylu antologicznego z pism prorockich i sapiencjalnych; niemal każda apokalipsa posługuje się schematami biblijnymi. Natomiast midrasz strukturalny polega na włączaniu własnych treśsi w strukturę myśli biblijnej (np. 1 Hen 90, 13-19 jako midrasz do Ez 34) lub na przejęciu sformułowań biblijnych, stanowiących jakby teksty dowodowe, aby wyrazić własną koncepcję religijną (np. Wniebowzięcie Mojżesza 10, 1-10). ${ }^{40}$

$\mathrm{U}$ podstaw interpretacji Biblii w apokalipsach leży założenie, że istnieją dwa objawienia Boże: objawienie powszechne, dostępne dla wszystkich i pewne objawienie, okryte tajemnica, dostępne tylko dla wybranych. W przeciwstawieniu do judaizmu świątynnego, apokaliptyka zajmuje pozycję defensywną i ekskluzywistyczną w stosunku do przemian kulturowych, ale za to $\mathrm{w}$ przeciwstawieniu do judaizmu synagogalnego, apokaliptyka zachowuje kultową, sakramentalną wizję dziejów. Podczas gdy w judaizmie synagogalnym historię świętą traktuje się jako pełne i ostateczne objawienie wybrania i powołania Izraela, w apokaliptyce historia święta jest ujmowana profetycznie (zawiera typy lub rodzaj snów mających się spełnić w przyszłości), wskazując na nowe objawienia wybrania i powołania prawdziwego, wiernego Izraela.

Gatunek literacki zwany testamentami niektórzy uczeni traktują jako bezpośrednią interpretację Pisma Swiętego ${ }^{41}$. Testamenty zawierają idealizację postaci biblijnych i reinterpretację tekstów biblijnych w świetle etosu żydowskiego, głównie $\mathrm{z}$ kół pietystycznych. W testamentach spotykamy formę interpretacji tekstów biblijnych zwaną midraszem parenetycznym.

Teksty poszerzające Stary Testament to takie utwory, w których op wwiadanie i tekst biblijny stanowią całość. Nazywa się je midraszem narracyjnym lub nowelą aretologiczną. Do takich utworów należy np. Życie Adama i Ewy, Józef $i$ Asenet oraz Liber antiquitatum Pseudo-Filona.

b) Ma'aseh Merkabah

Z apokaliptyką wiąże się nurt mistycznych interpretacji tronu Bożego z wizji Izajasza i Ezechiela pod nazwą ma'aseh merkabah dzieło tronu, rydwanu ${ }^{42}$. Pełny wyraz znalazła ta interpretacja $\mathrm{w}$ he-

40 Por. D. Patte, dz. cyt., $181-199$.

41 Tak np. G. W. E. N ickels burg, Jewish Literature Between the Bible and the Mishnah. Philadelphia 1981, 231-256.

$42 \mathrm{Z}$ bogatej literatury tego tematu por. C. Rowland, The Visions of God in Apocalyptic Literature, "Journal for the Study of Judaism" 10 (1979) 137-154; I. Gruenwald, Apocalyptic and Merkavah Mysticism (Arbeiten zur Geschichte des antiken Judentums und des Urchristentums 14), Leiden 1980; D. J. H a l perin, The Merkavah in Rabbinic Literature (American Oriental Series 62), New Haven 1980; I. Ch ernus, Visions of God in Merkabah Mysticism, JSJ 13 (1982) 123-146; P.-M. B o ga e rt, 
brajskiej Księdze Henocha (3 Hen) i w Hekalot rabbati. Zarówno 3 Hen, jak równiez inne teksty mistyki merkabah są przypisywane rabbiemu Jiszmaelowi, który zmarł na krótko przed powstaniem Bach Kochby w 132 r. Oczywiście przypisywanie tych tekstów rabbiemu Jiszmaelowi ma charakter umowny, ale z Talmudu (Hagiga 2, 1; b. Sanh 80 b) można wywnioskować, że ten nurt w II w. po Chr. już był w pełni rozwinięty.Obejmowal on ryt wtajemniczenia, mistyczne doświadczenia adeptów, recytacje modlitw i hymnów. Natomiast do $70 \mathrm{r}$. po Chr. mistyka merkabah rozwijała się w ramach apokaliptyki.

Przypuszcza się, że mistyka merkabah sięga czasu powstania Ksiąg Kronik, gdyż w $1 \mathrm{Krn} \mathrm{28,18}$ słowo merkabah zostało użyte w znaezeniu technicznym stosowanym w mistyce żydowskiej. W tym tekście jest mowa o Dawidzie, który przekazuje Salomonowi plan rydwanu ze złotymi cherubami rozciągającymi swe skrzydła i pokrywającymi Arkę przymierza. Autor opisuje Arkę przymierza pod wpływem Ez 1,10 i $43,3-4$.

Na pewno w znaczeniu technicznym zostało użyte słowo merkabah w Syr 49, 8. W tym miejscu tekst hebrajski różni się od greckiego. W tekście hebrajskim czytamy: „Ezechiel otrzymał wizję i opisał różne jakości rydwanu". Głównie chodzi tu o opis zwierząt, ale autor ma na uwadze także inne elementy rydwanu, jak koła, ogień itp.

W Kumran świadectwem przedchrześcijańskiej mistyki żydowskiej jest Pieśń ofiar sobotnich (4QShir Shab). Zachowały się dwa fragmenty tego dzieła opisującego liturgię niebiańską. Jeden fragment zawiera opis tronu-rydwanu Bożego.

\section{c) Formy interpretacji Biblii w Kumran}

Uważając siebie za lud Nowego Przymierza, prawdziwą resztę Izraela żyjącego na końcu czasów, członkowie gminy kumrańskiej wierzyli, że są stróżami czystości i autentyczności prawdy kapłańskiej oraz właściwego wyjaśniania Pisma świętego, wyjaśniania objawionego Nauczycielowi Sprawiedliwości, „któremu Bóg ukazał wszystkie tajemnice słów swoich sług proroków" (1QpHab 7, 4-5). Stąd z wyjątkiem Zwoju Miedzianego i nielicznych fragmentów, teksty kumrańskie to odpisy Biblii lub dzieła opierające się na niej. W rękopisach niebiblijnych znajdują się zarówno cytaty wyraźne z Biblii, jak też cytaty ukryte, aluzje do tekstów biblijnych i reminiscencje biblijne (np. w 1QS, 1QSa, 1QM, CD). Kilkanaście dokumentów kumrańskich to systematyczne komentarze tekstów prorockich (peszarim) lub antologie tekstów biblijnych z wyjaśnieniem (4QFlor; 11

Recherches actuelles sur l'ancienne mystique juive. A propos de l'édition synoptique des traités sur Hékhalot, „Revue Théologique de Louvain” 14 (1983) $215-220$. 
QMelch). Niektóre dokumenty stanowią przeróbkę utworów biblijnych (np. 1QGenApocr), inne są wzorowane na utworach biblijnych (np. $1 \mathrm{QH})$ lub zawieraja tradycje paralelne do tradycji biblijnych (4QPrNab 4QPSSJoz) ${ }^{43}$.

G. Vermes ${ }^{44}$ wyróżnia sześć form interpretacji Biblii w Kumran:

1) Peszer;

2) Parafrazy większych jednostek w formie midraszu;

3) Parafrazy mniejszych jednostek w formie midraszu;

4) Zbiory tekstów dowodowych (testimonia);

5) Zbiory tekstów prawnych ułożonych tematycznie (halacha);

6) Zbiory tematyczne tekstów dokrynalnych.

Peszer stanowi owoc systematycznej interpretacji tekstów biblijnych podanej przez Nauczyciela Sprawiedliwości, którą początkowo przekazywano ustnie. Do tej grupy należy kilkanaście komentarzy z czasów Heroda Wielkiego (komentarz do Księgi Habakuka, Nahuma, Izajasza, Ozeasza, Ps 37 itp.). J. T. Milik ${ }^{45}$ przypuszcza, że mogły one one powstać w kontekście nieprzerwanego studiowania Biblii, w czasie którego czytano i wyjaśniano wiersz po wierszu. Istnieje możliwość kontekstu liturgicznego.

Wyróżnia się dwa rodzaje komentarzy kumrańskich zwanych peszerami: peszer ciągły i peszer tematyczny.

Inną formą interpretacji tekstów świętych w Kumran są parafrazy większych jednostek biblijnych w formie midraszu. Przykładem jest Apokryficzna Księga Rodzaju, która włącza tekst biblijny w większe opowiadanie. Weimar nazywa to dzieło midraszem narracyjnym.

Midrasz rozwijający mniejsze jednostki biblijne znajduje się w Dokumencie Damasceńskim. Testimonia to zbiór tekstów mesjańskich z 4Q, które podają podstawę biblijną oczekiwań wspólnoty na proroka i dwóch Mesjaszów: Aarona i Izraela.

Halacha kumrańska jest poświadczona w Dokumencie Damasceńskim, Regule Zrzeszenia, Regule Wojny i Zwoju Swiątyni. L. H. Schiffman ${ }^{46}$ wyróżnia kilka form halachy kumrańskiej. Na szczególną uwagę zasługują: niglot, nistarot, perusz i midrasz. Niglot to takie prawa biblijne, które nie wymagają objaśnienia, gdyż ich sens jest oczywisty. Nistarot są to prawa ukryte w Biblii, które znają tylko członkowie gminy kumrańskiej, mając właściwe rozumienie Pisma. Perusz

43 Z nowszych publikacji dotyczących egzegezy Pisma świętego w Kumran por. D. P a t t e, dz. cyt., 209-231; M. P. H or g a n, Pesharim: Qumran Interpretations of Bibiical Books (CBQMS 8), Washington 1979; G. J. Brooke, Exegesis at Qumran. 4QFlorilegium in its Jewiwsh Context (JSOT Suppl. Ser. 29), Sheffield 1985.

44 History of Interpretation at Qumran and in the Targums, w: The Interpreter's Dictionary Supplementary Volume, Nashville 1976, 438-443.

${ }_{45}$ Dziesięć lat odkryć na Pustyni Judzkiej, Warszawa 1968, 41.

40 The Halakha at Qumran (Studies in Judaism in Late Antiquity 16), Leiden 1975. 
polega na takim wyjaśnieniu tekstu biblijnego, że nie ma potrzeby odnoszenia się do innego tekstu. Wreszcie midrasz w Kumran oznacza taką formę halachy, w której jeden tekst biblijny jest wyjaśniany przez inny tekst.

Zbiór tematyczny tekstów doktrynalnych znajduje się w Dokumencie Damasceńskim, w Komentarzu na czasy ostateczne i w dokumencie na temat Melchizedeka (11QMelch).

\section{d) Egzegeza Filona z Aleksandrii}

Odrębne, ale ważne zagadnienie dla tła Nowego Testamentu, stanowi egzegeza Filona $\mathbf{z}$ Aleksandrii. Filon $\mathbf{z}$ Aleksandrii uprawiał działalność kaznodziejską w synagodze aleksandryjskiej, dlatego jego egzegeza ma charakter homiletyczny, ale głównym jej źródłem jest osobiste studium Pisma świętego i prywatna pobożność. Filon rozwinął egzegezę kultywowaną przed nim w środowisku aleksandryiskim, zwłaszcza po linii Septuaginty, ale ją urozmaicił i ubogacił ${ }^{47}$. Tradycyjna egzegeza aleksandryjska rozwijała budujące przykłady historii świętej, stosując greckie formy literackie. $\mathrm{Na}$ tym rodziły się jednak liczne nadużycia, które Filon zwalcza i koryguje. Przeciwstawia się on trzem kierunkom interpretacji Biblii: 1) Interpretacji ludzi niewykształconych, która dochodziła do absurdów w pojęciach teologicznych (np. oblicze Boże przeciw bezbożności epikurejczyków i idololatrii Egipcjan); 2) Interpretacji synkretystycznej, która nie dostrzegała transcendencji Biblii i identyfikowała ją z innymi pismami religijnymi otaczającego śwata; 3) Interpretacji literalnej Żydów wykształconych, ale kurczowo trzymających się ujęć tradycyjnych.

Filon uprawia egzegezę dosłowną i alegoryczną. Na pierwszym miejscu stara się odkryć właściwy sens biblijny. Często wskazuje, że sens właściwy ma charakter przenośny (np. opis stworzenia świata). W tym celu zwraca on uwagę na gramatykę, retorykę i arytmetykę. Ale w sferze kosmologii, antropologii i mistyki Filon nie trzyma się sensu wyrazowego Biblii, lecz uprawia egzegezę alegoryczną (np. De migratione Abrahae wyjaśnia jako obraz mistycznej wędrówki duszy do Boga).

Filon posługiwał się językiem Platona, żeby ukazać, iż Pismo święte zawiera mądrość wyższą od mądrości greckiej. W egzegezie podkreśla on niepojętość Boga i zasadniczą różnicę między Bogiem a stworzeniem. Bóg objawia się w świecie przez działania. Wyróżnia

47 Por. B. L. M a c k, Exegetical Traditions in Alexandrian Judaism. A Program for the Analysis of the Philonic Corpus, "Studia Philonica" 3 (1974-75) 21-112; R. D. He cht, Scripture and Commentary in Philo, w: Society of Biblical Literature 1981 Seminar Papers, ed. K. R i c hars, Chico 1981, 129-164; R. A rnaldez, L'Influence de la traduction des Septante sur le commentaire de Philon, w: Etudes sur le judaïsme ruellénistique, Paris 1984, 251-266. 
on pięć działań Bożych: działanie stwórcze, rządy Boże w świecie, miłosierdzie, działanie nakazujące, co należy czynić (królowanie Boga) i działanie zakazujące, czego należy unikać. Istotę religii stanowi uczczenie działania Bożego przez człowieka, a więc odrzucenie grzechu, posłuszeństwo prawu, zawierzenie miłosierdziu Bożemu, poddanie się pod królowanie Boga, przylgnięcie do miłości Stworzyciela.

Doktryna o działaniu Bożym w świecie jest związana $z$ pojęciem Logosu u Filona. Większość komentatorów upartuje w Logosie Filona hipostazę pośrednią między Bogiem a światem. Ale za H. A. Wolfsonem należy wyróżnić w nauce Filona o Logosie trzy aspekty: Logos niestworzony, którym jest nous Boży i który nie ma odrębnego istnienia; Logos stworzony, który jest jednością świata zrozumiałego; Logos immanentny, który działa w stworzeniach rozumnych ${ }^{48}$

\section{PODSUMOWANIE}

To pobieżne spojrzenie na formy interpretacji Biblii $\mathrm{w}$ judaizmie okresu międzytestamentalnego przekonuje nas o różnorodności sposobów przekazywania słowa Bożego w zależności od środowiska, rodzaju wspólnoty religijnej i przyjmowanych założeń hermeneutycznych. W oparciu o aktualną dokumentację i stan badań tekstów nie można jeszcze dokładnie zweryfikować zależności form interpretacji Biblii od charakteru wspólnoty religijnej, ale nie ulega wątpliwości, $\dot{z e}$ faryzeusze nie byli jedynymi przekazicielami i interpretatorami Biblii w okresie międzytestamentalnym.

Warszawa

KS. STANISŁAW MEDALA CM

$48 \mathrm{Philo}$. Foundation of Religious Philosophy in Judaism, Christianity and Islam, Cambridge, Mass.2 1948, t. I, s. 200-294.

Ks. Jan Lach

\section{OBOWIAZZEK POJEDNANIA I MILOŚCI (Mt 5, 43-48)}

Problem interpretacji ostatniej, szóstej antytezy $z$ Kazania na Górze wydaje się właściwie zamykać w zrozumieniu tego, co mieści w sobie tekst Mt 5, 43-47'. Uważa się zwykle, że następujący po

1 Zob. A. S a nd, Das Gesetz und die Propheten. Untersuchungen zur Theologie des Evengelïums nach Matthäus, Regensburg 1974, 54-56; G. Strecker, Die Antithesen der Bergpredigt (Mt 5, $21-48$ par.), ZNW 